\title{
Children and International R elations: a new site of knowledge?
}

\author{
ALISON M.S. WATSON*
}

\begin{abstract}
A bstract. R ecent years have seen the growth of approaches critical of traditional state-centred examinations of international relations, arguing instead for analyses that recognise actors and methods previously held largely silent within the mainstream International R elations (IR) discourse. This article argues that children are a group of actors worthy of similar recognition. Despite the fact that 'childhood studies' are comparatively well established in a number of academic disciplines, similar recognition has been later in coming to the study of IR. This article aims to address this perceived gap in the literature by first of all outlining the ways in which the discourse surrounding the child in IR has so far developed. This leads into an examination of how the child may potentially best be conceptualised within the mainstream discourse and the implications of the inclusion of children as a 'site of knowledge' through which the international system may be more clearly understood.
\end{abstract}

R ecent years have seen the growth of approaches critical of traditional state-centred examinations of international relations, arguing instead for analyses that recognise actors and methods previously held largely silent within the mainstream International R elations discourse. ${ }^{1}$ This article argues that children are a group of actors worthy of similar recognition. Since the adoption of the $U N$ Convention on the Rights of the Child (U N CR C) in 1989, and its ratification by almost every country in the world, ${ }^{2}$ children occupy a position that child rights advocates argue places them centre-stage in the quest for the universal application of human rights. They also play a variety of roles in the international system. They labour - estimates suggest that around 246 million children worldwide are engaged in child labour. ${ }^{3}$

* A n earlier version of this article was presented at the International Studies A ssociation Convention, M ontreal, M arch 2004. The author would like to thank participants in the panel 'The Vulnerable at the F ringes of IR', for their helpful comments at that time. The author would also like to thank Cynthia Enloe and Oliver Richmond for their comments at various stages of the writing process, $\mathrm{D}$ avid A rmstrong, the editor at the time that this paper was reviewed and accepted, and also the two anonymous referees who provided such helpful advice. All errors remain the author's own.

1 See, for example: B. A rts, M. N oortman, and B. R einalda (eds.), Non-state Actors in International Relations (A Idershot: A shgate, 2001); R. F alk, 'The G lobal Promise of Social M ovements at the Edge of Time', Alternatives: Social Transformation and Humane Governance, 12 (1987), pp. 173-96; and M. H offman, 'C ritical Theory and the Inter-paradigm D ebate', Millennium: Journal of International Studies, 16:2 (1987), pp. 231-49.

2 The only countries not to sign up to the UNCRC are the U nited States and Somalia, although Somalia did sign up to the Convention during the U nited N ations G eneral A ssembly Special Session on Children, held in $\mathrm{M}$ ay 2002, and at that time committed to ratification.

3 〈http://www.unicef〉. Child labour is defined as involving children below the age of 12 that are working in any economic activities, those aged 12 to 14 years that are engaged in harmful work, and all children that are engaged in the worst forms of child labour. The latter, in addition to the involvement of children in slavery, prostitution, pornography, and drug trafficking, includes work that is likely to jeopardise the health, safety or morals of young persons. See International L abour Organisation (IL O), Convention 182: Convention on the Worst Forms of Child Labor (G eneva: ILO, 1999). 
They fight - the use of child soldiers in war continues, and in some countries has increased. ${ }^{4}$ They seek refuge - there are over 40 million people displaced by conflict or human rights violations, ${ }^{5}$ more than half of whom are children. ${ }^{6}$ They consume: in rich countries in particular, the child has become an important customer in the effort to sell more goods. ${ }^{7}$ Children also participate in a variety of events at local, regional, national and international levels at which they voice, and/or are encouraged to voice, their concerns. ${ }^{8}$ In N orway, for example, there are Children's $\mathrm{M}$ unicipal Committees, where children are given part of the municipality's budget and are allowed to decide how that part is allocated with regard to youth activities in their areas; ${ }^{9}$ whilst the U N Special Session on Children held in M ay 2002 was significant, not only because it was the first such Session devoted exclusively to children, but also because it was the first to include them as official delegates. ${ }^{10}$

This variety of roles that children play within global society has not gone unrecognised and a plethora of studies now examine the potential place of children as social actors. H owever, despite the fact that 'childhood studies' are comparatively well established in a number of academic disciplines, similar recognition has been later in coming to the academic study of international relations. Rather, in the

${ }^{4}$ See, for example: 〈http://news.bbc.co.uk/2/hi/africa/3401991.stm〉 and also 〈http://www.hrw.org/ campaigns/crp/index.htm $\rangle$. Current estimates suggest that around 300,000 children are being used as soldiers in more than thirty countries around the world, including A ngola, Colombia, Lebanon, Liberia, Sierra L eone, Sudan and U ganda. At this point, it is useful to note that much of the literature concentrates on the generic 'child soldier', in actuality spending more time on the detailing of boys' experience in such roles. In many cases, however, the experience of girl soldiers is a different one, and one that has proved to be more intransigent in terms of efforts towards their post-conflict reintegration into society. See D yan M azurana and Susan M cK ay, 'Child Soldiers: What A bout the Girls?', Bulletin of the Atomic Scientists, 57:5 (2001), pp. 30-5.

${ }^{5} \mathrm{G}$ raca M ichel, The Impact of War on Children (L ondon: H urst and Co., 2001), p. 26.

${ }^{6}$ Of course the counter-argument that can be made here is that whether children decide that they have to fight, or to labour, or to migrate for reasons of self-preservation, such decisions, and the fact that they have to be made, are in themselves a form of coercion. There are economic, cultural, social or political factors that have left these children with no alternative but to make such decisions.

7 Sandy H obbs, J im M CK echnie and M ichael L avalette, Child Labour: A World History Companion (Oxford: A BC-CLIO Europe, 1999), p. 213. As an interesting example of the power of children to affect consumption habits, it is often children who have more information, frequently derived from school, regarding ethical consumption choices. Such ethical considerations may then lead to changes in consumption habits (for example, to buying fairly traded products) which may in turn have a long-term impact upon the international division of labour. Their influence therefore extends beyond their own purchases to the purchases that their parents make, including travel, computers, food, entertainment, and even cars.

8 〈http://www.plan-uk.org/pdfs/literaturereview.pdf), p. 12.

${ }^{9} \mathrm{As}$ another examples of this, in Barra M ansa in Brazil, a children's participatory budget council has been developed in which 18 boys and 18 girls (between the ages of 9 and 15) have been elected by their peers as a way of ensuring that the municipal council addresses their needs and priorities. See Eliana Guerra, 'Citizenship knows no age: children's participation in the governance and municipal budget of Barra M ansa, Brazil', Environment and Urbanization, 14:2 (October 2002), pp. 71-84.

10 Of course the question that arises with all such examples is the extent to which children are still being manipulated in some way by adults. Even those organisations - private and public, national and international - that have emerged to advocate children's rights, it can be argued, are acting simply as an alternative source of opinion in the arguments regarding what is in a child's best interests, often rather than letting the child speak for itself. This is a criticism that a number of N G Os have taken on board, with the result that it is now commonplace to be able to read first-hand accounts of particular children's experiences, whether on the NG O's website or in any reports that they may release, and for children themselves to participate in online discussions where they have the opportunity of putting their views across. The question still remains, however, of how much any such interventions translate through to an active policy stance that directly involves the child. 
majority of the mainstream IR discourse, the child remains a silent force - very few writers address in any critical way either their role, or the implications of conceptualising it. This article aims to address this perceived gap in the literature by first of all outlining the ways in which the discourse surrounding the child in IR has so far developed. This also includes a brief examination of their current place in the wider social sciences literature. This leads into an examination of how the child may potentially best be conceptualised within the mainstream discourse, including how they could potentially best be portrayed in existing literatures, and the reasons for their current absence from those same literatures. This develops into an examination of the implications for the existing IR discourse of the inclusion of children as a 'site of knowledge' through which the international system may be more clearly understood. The final section summarises.

\section{The development of a discourse}

The discourse that surrounds the study of the child within the social sciences is one that recognises children, and the social structures that result from their presence, as a potential 'site of knowledge', and has ranged from critical thinking about the nature of education, to analyses of the child's place in history. Crucial to the latter was the work of French historian Philippe Aries, who published the English translation of his Centuries of Childhood in 1962. A Ithough somewhat flawed in its approach, A ries' work opened up the study of children not only for historians, but for those in other disciplines as well and from the 1980s onwards, an array of social scientists working in fields as diverse as anthropology, economics, geography, history, philosophy, social psychology, social policy and sociology began, to a greater or lesser extent, to study children in ways different to those that had previously prevailed.11 In particular, they began to observe and understand how children plan and understand their lives as 'rational agents', 12 examining the reasons not only why children behave as they do, but also how socially constructed notions of childhood may effect our understanding of such behaviours. The interest generated as a result of such studies has been enough to warrant the creation of several academic journals, such as Childhood: A Global Journal of Child Research, and Children's Geographies, as well as the International Journal of Children's Rights, and special sections in international academic associations devoted to childhood studies, such as the 'R esearch Committee on the Sociology of Childhood' of the International Sociological A ssociation. There are international conferences devoted to the study of children and all aspects of their childhoods, ${ }^{13}$ and a significant number of websites

11 See, for example, G. Boas, The Cult of Childhood (L ondon: Warburg Institute, 1996); J. C. H olt, Escape from Childhood: The Needs and Rights of Children (London: Penguin, 1975); J ens Qvortrup, M arjetta Bardy, Giovanni Sgritta, and H elmut W intersberger (eds.), Childhood Matters, Social Theory, Practice and Politics (A vebury, 1994); Berry M ayall, Towards a Sociology of Childhood (Buckingham: Open U niversity Press, 2002); A llison James and A lan Prout (eds.), Constructing and Reconstructing Childhood (L ondon: R outledge, 1997).

12 Priscilla A Iderson, Institutional Rites and Rights: A Century of Childhood (L ondon: Institute of Education, 2003), pp. 27-29.

13 One of the most major of these being the Childhoods conference (Children and $Y$ outh in Emerging and Transforming Societies) held in Oslo in J une 2005, and involving over 1,000 participants. 
that provide an ongoing commentary on children's lives, and the circumstances that may affect them.

In the case of the discourse that specifically surrounds the analysis of international relations, however, the study of children could be characterised as still being on the fringes of the discipline, despite the body of work that already exists in areas traditionally seen as being of interest to international relations scholars. ${ }^{14}$ Perhaps surprisingly, the presence of children in such work is not recent. If we chart the history of the concept of childhood, we find that we are very much tracing the history of European political thought. A ugustine, for example, in his writings, essentially constructed 'a theology of childhood', 15 whilst L ocke presented what is tantamount to a theory of children's rights, arguing that children have the same moral rights as any other person, though the child's inadequate mental faculties make it permissible for his parents to rule over him to a limited degree. ${ }^{16} \mathrm{M}$ arxian political thought, meanwhile, singled out child labour as an example of a particularly exploitative labour relationship.

$\mathrm{N}$ evertheless it is in more recent writings that the potential to carve out a place within the mainstream IR discourse can more obviously be seen. Thus, for example, and as has been noted elsewhere, ${ }^{17} \mathrm{G}$ uy Goodwin-G ill and I lene Cohn have written on child soldiers, Ed Cairns has written on the impact of political violence on children, $\mathrm{F}$ raser $\mathrm{M}$ orris has written of children in conflict situations, J ames $\mathrm{M}$ arten has written on children and war, and J enny $\mathrm{K}$ uper has written on the international legal position of child civilians in armed conflict. Such analyses are important because, although not written by authors who themselves inhabit the mainstream IR discourse (G uy Goodwin-Gill, Ilene Cohn and J enny K uper principally write from their perspective as experts in international humanitarian law; $\mathrm{Ed} C$ airns and $\mathrm{F}$ raser $M$ orris are psychologists, and James $M$ arten is a historian), they nevertheless map out the territory within which potential analyses of children's significance to the discipline may take place.

One of the first such analyses was a chapter published by Norman Lewis in the 1998 edited volume Human Rights Fifty Years On. In his analysis of '[h]uman rights, law and democracy in an unfree world', Lewis examines the issue of the 'rightsbearing subject', in particular using the case of the increased emphasis upon children's rights, reflected in documents like the UNCRC, to argue that rather than safeguarding human rights, 'the elevation of the human rights discourse represents ... a fundamental attack upon democratic freedoms and rights . . from civil and political rights in the domestic sphere, to national rights in the international sphere'. ${ }^{18}$ L ewis' analysis is significant in that it demonstrates the potential

14 This can be seen even with regard to the subject of this article. When an earlier version was presented at the 2004 ISA conference in M ontreal, it was assigned, along with a number of other papers on children, to a panel entitled 'The Vulnerable at the F ringes of IR', the inherent assumption therefore being that children are not relevant subjects of study for mainstream discourse.

15 M artha Ellen Stortz, ' "Where or When W as Y our Servant Innocent?" A ugustine on Childhood', in M arcia J. Bunge (ed.), The Child in Christian Thought (Eerdmans, 2001).

16 See Bryan Caplan, 'L ocke, Consent and the Rights of Children', 〈http://www.libertarian.co.uk/ lapubs/philn/philn045.pdf $\rangle$.

17 A lison M. S. W atson, 'Seen But N ot Heard: The R ole of the Child in International Political Economy', New Political Economy, 9:1 (1994).

18 N orman L ewis, 'H uman R ights, L aw and D emocracy in an U nfree W orld', in Tony Evans (ed.), Human Rights Fifty Years On: A Reappraisal (M anchester: M anchester U niversity Press, 1998), pp. 98, 79 . 
importance of children as a 'site of knowledge' within mainstream IR discourse. F ar from being a subject that inhabits the fringes of the discourse, he argues that the way in which the existing international legal framework encounters the child in actuality defines the ability of developing states in particular 'to fulfil the criteria of legitimate state behaviour.'19 Children's rights, in other words, and the desire to give all children what may be considered to be an idealised version of childhood, may serve as an excuse for intervention in a state's domestic affairs that ultimately destroys the sovereign status of the state. ${ }^{20}$ Similar issues are raised by Vanessa Pupavac in her work on the international children's rights regime, and her argument for the recognition that children's issues serve to guide the formation of humanitarian principles under international law. ${ }^{21}$ Pupavac also examines issues of psycho-social intervention, arguing that such policies may represent a 'preoccupation with deviancy', and again questions whether the existing child rights regime may actually 'institutionalise a more unequal international system'.22

F or a number of authors, it is the place of children, or specific groups of children, during conflict and its aftermath that provide the space in which children's place in the international system can best be analysed. $\mathrm{N}$ ew publications in this area include Helen Brocklehurst's forthcoming Who's Afraid of Children: Children Conflict and Global Politics, ${ }^{23}$ and Siobhan M CEvoy-Levy's edited volume Troublemakers or Peacemakers? Youth and Post-Accord Peacebuilding, ${ }^{24}$ but it also includes work such as Carpenter's analyses of children born of wartime rape, ${ }^{25} \mathrm{D}$ eBerry's work on child soldiers and the UNCRC, ${ }^{26} \mathrm{H}$ ick's work on the political economy of war-affected children, ${ }^{27}$ and Thompson's analysis of the citizenship issues surrounding children in M ozambique. ${ }^{28} \mathrm{~N}$ otable too is the considerable body of work, from the $1950 \mathrm{~s}$ and 1960s onwards, on how children acquire their political beliefs, either with regard to allegiance to a particular political party, to how they view political authority, or to the creation, or not, of nationalist feeling. 29

The studies above all recognise the necessity for further analyses of the child's role to take place. A cknowledging this need, in 2001 the Journal of International Affairs

19 Ibid., p. 96.

20 Ibid., p. 96.

21 Vanessa Pupavac, 'The International Children's R ights R egime', in D avid Chandler (ed.), Rethinking Human Rights: Critical Approaches to International Politics (Basingstoke: Palgrave, 2002), pp. 57-75.

22 Vanessa Pupavac, 'M isanthropy W ithout Borders: The International Children's R ights R egime', Disasters, $25: 2$ (2001), p. 95.

23 Helen Brocklehurst, Who's Afraid of Children: Children Conflict and Global Politics (A Idershot: A shgate, forthcoming).

24 Siobhan M cE voy-L evy (ed.), Troublemakers or Peacemakers? Youth and Post-Accord Peacebuilding (U niversity of N otre D ame Press, 2006).

${ }^{25}$ Charli Carpenter, 'Surfacing Children: Limitations of G enocidal Rape D iscourse', in Human Rights Quarterly, 22:2 (M ay 2000).

$26 \mathrm{~J}$. D eBerry, 'Child Soldiers and the Convention on the Rights of the Child', Annals of the American Academy of Political and Social Science, no. 575 (M ay 2001), pp. 92-105.

27 Steve H icks, 'The Political E conomy of War-A ffected Children', Annals of the American Academy of Political and Social Science, no. 575 (M ay 2001), pp. 106-21.

${ }^{28}$ Carol B. Thompson, 'Beyond Civil Society: Child Soldiers as Citizens in M ozambique', Review of African Political Economy, 26:80, pp. 190-206.

29 See, for example: Gabriel A Imond and Sidney Verba, The Civic Culture: Political Culture and Democracy in Five Nations (Princeton, N J : Princeton U niversity Press, 1963); K aren Orren and Paul Peterson, 'Presidential A ssassination: A Case Study in the D ynamics of Political Socialisation', The Journal of Politics, 29 (M ay 1967), pp. 388-409; and P. Beck and M. Jennings, 'Pathways to Participation', American Political Science Review, 76 (M arch 1970), pp. 94-108. 
published a special issue on Children: Challenges and Prospects for the New Millennium, ${ }^{30}$ with articles covering such diverse areas as the impact upon children of forced migration, the question of early childhood development, and the issue of inter-country adoption; whilst in that same year the Annals of the American Academy of Political and Social Science published a special issue on Children's R ights. ${ }^{31}$ W orks such as these help to identify the wide variety of areas in which a greater understanding may add to existing explanations of the way in which the international system operates. They also underline the need that remains for a more thorough examination of the potential place of the child within the mainstream discourse to take place, because although the existing body of work does much to elucidate the issues that surround children, problems of under-theorisation and underconceptualisation remain. Little is said, for example, on the ways in which mainstream theory could potentially find a space for the child, or of the ways in which the extensive 'childhood studies' literature could help to elucidate a number of ongoing debates. Before examining the reasons for such problems and how they may be addressed, however, there remains one body of work within the existing literature that must, because of its implicit examination of a number of the issues surrounding the place of children in international relations, first be discussed.

F eminist authors criticise the traditional siting of women within the private space. According to Pateman, this public-private distinction is the single most important issue for feminism. ${ }^{32} \mathrm{H}$ owever the charge that the private space is the one that women inhabit is largely predicated on their assumed role as mothers. This has led, as J ean Bethke E Ishtain has noted, to children being 'the companions of women in the closet of political science'. ${ }^{33} \mathrm{H}$ ooper has argued that such public-private distinctions result in the categorisation of modern life into a variety of separate spaces that are highly gendered, ${ }^{34}$ but arguably such spaces may be said to be 'highly kindered' too. Children, and the various roles that they play, have thus been assumed to be outside the traditional field of IR - 'distant from the epicentres of power'35 - their activities largely occupying lowly positions in the public sphere or being wholly confined to the private or domestic realms. ${ }^{36}$

Moreover international law, and the discourse that surrounds it, reiterates this grouping together of women and children. As Puechguirbal argues, it is as if a new category of human beings has been created, known as 'women-and-children'. ${ }^{37}$ This

30 Children: Challenges and Prospects for the N ew M illennium, Journal of International Affairs, 55:1 (F all 2001).

31 Children's Rights, Annals of the American Academy of Political and Social Science, no. 575 (M ay 2001).

32 Carole Pateman, 'F eminist Critiques of the Public/Private Dichotomy', in The Disorder of Women: Democracy, Feminism, and Political Theory (Cambridge: Polity Press, 1989).

33 J ean Bethke Elshtain, The Family in Political Thought (A mhurst, M A : U niversity of M assachusetts Press, 1982), p. 289.

34 Charlotte H ooper, Manly States (N ew Y ork: Columbia U niversity Press, 2001), p. 92.

35 A Ima Gottlieb, The Afterlife Is Where We Come From (Chicago, IL: U niversity of Chicago Press, 2004), pp. 49-50.

36 See Cynthia Enloe, Bananas, Beaches and Bases (Stanford, CA: U niversity of California Press, 1990). Once again, such segregation between public and private space can be seen as a highly W estern construction. F or example, Gottlieb notes (p. 5), that 'A merican society segregates people by age quite systematically. Children typically inhabit different social spaces from those populated by adults.' G ottlieb, ibid., p. 5.

37 N adine Puechguirbal, 'W omen and Children: D econstructing a Paradigm', Seton Hall Journal of International Relations', p. 5. 
in turn can be argued to impact upon women's ability to find a place of their own within the discourse - 'an "agency" that builds the framework of an identity undefined by subordination to male power' 38 - and it arguably impacts upon the place of children within the discourse in a very similar way. By grouping together women and children, both achieve a lack of status that is predicated on the liberal division between the public and the private spheres. H owever, for the role of children in IR, and in IR more generally, such public-private distinctions are, as is the case for women, no longer accurate, and indeed may hamper the examination of other dynamics that feed into the international discourse. Recognising the variety of political spheres that exist - public and private - and the interaction that takes place between them may thus provide a much more accurate presentation of global political life, ${ }^{39}$ and indeed may challenge what Richard Ashley has called 'the paradigm of sovereign man.' 40

\section{A potential conceptualisation}

If children are ever to be fully acknowledged as actors within mainstream IR discourse, the nature of the role that they play must first be understood and conceptualised. In the case of the 'childhood studies' discourse within other social sciences, one of the first ways in which this was achieved was to examine not only the role that children have played throughout history, but also the approaches that have been used to explain the significance of that role and how they themselves may 'have produced ... misleading underestimations [of] ... children'. ${ }^{41}$ Indeed, as H olloway and Valentine have noted, the delineation of children as 'other' to adults is a convention challenged by those academics who argue that our current conception of children, particularly in the North, 'as being less developed, less able and less competent than adults' is one that is 'historically specific.' 42

Thus, in a similar way to how feminist scholarship has elucidated the involvement of women in political struggle, studies of the role of children in society through the ages have been instrumental in 'restoring them to the stage from the wings of history'. ${ }^{43} \mathrm{~A} n \mathrm{IR}$ discourse that incorporates the place of the child should thus, in addition to acknowledging their contemporary significance, also take into consideration their historical significance too, and indeed how that significance has altered down the years according to the historical accounts of their activity.

38 Ibid., p. 12.

39 R oland Blieker, Popular Dissent, Human Agency and Global Politics (Cambridge U niversity Press, 2000), p. 274-5.

40 Richard K. A shley, 'Living on Border Lines: M an, Poststructuralism and War', in J. Der Derian and M.J. Shapiro (eds.), International/Intertextual Relations: Postmodern Readings of World Politics (L exington Books, 1989), pp. 269, 299.

41 A lderson, Institutional Rites and Rights, pp. 27-9.

42 Sarah L. Holloway and Gill Valentine, 'Children's G eographies and the N ew Social Studies of Childhood', in Sarah L. Holloway and G ill Valentine (eds.), Children's Geographies (R outledge, 2001), p. 2. Moreover, the '18' threshold can be argued to be in itself a very Western concept, and one form of 'cultural convention premised on the W estern calendar', see G ottlieb, The Afterlife Is Where We Come From, p. 44.

43 Jean Bethke Elshtain, The Family in Political Thought. 
The involvement of children as actors in political struggle is not new, and history is littered with stories of children displaying what are now traditionally perceived to be adult qualities. A n early example is the Children's C rusade of 1212, when around 50,000 children set out from France and Germany with the aim of capturing J erusalem. Although none reached their destination, and few returned home, with most being sold into slavery, the enthusiasm excited by the Children's Crusade encouraged Pope Innocent III to summon the fifth C rusade. M ore than 500 years later, the most inspiring martyrs of the $F$ rench republic for $\mathrm{R}$ obespier re were two adolescent boys, Bara ('heroic child!') and Viala ('respectable child!') who died fighting against rebel forces on the banks of the $\mathrm{D}$ urnace. ${ }^{44} \mathrm{C}$ hildren are also present in the history of the A merican Civil War, in the first and second W orld Wars, in the Vietnam war, and in countless examples of regional and civil conflicts through the ages. A lthough it can be argued that the place of children in wartime is one that has become more significant in recent years, as conflict itself has changed, nevertheless, children have a place to play in the historical recounting of conflicts and their aftermath.

In addition to an awareness of children's position in history, conceptualising the child within the mainstream IR discourse would require an examination of how the impact of a position could potentially be theorised. N o international relations theory currently makes any specific reference to children as actors. The realist position, for example, with its traditional reliance on the state as the primary actor has had difficulty incorporating varieties of actors into its overarching theoretical standpoint. A ttempting to acknowledge a role for children within that standpoint is no different. In particular, a realist stance makes it difficult to consider the child as having rights of citizenship. For M achiavelli, for example, a well prepared and highly committed citizen militia is tantamount to having a sense of civic responsibility. Given that the military is largely male dominated, however, such a position not only excludes other groups in society - notably women and children - from the policy dialogue, but also from the notion of being a good citizen itself. $45 \mathrm{H}$ owever, such a position is very much reliant on the notion of what citizenship itself actually means, and indeed, as noted by E nnew, if age is a reason to exclude 'citizens' from franchise, then questioning this raises issues regarding the rights and duties of all citizens within a given society. ${ }^{46}$

D ifficulties arise too when examining the role of the child from a liberal viewpoint. The most obvious difficulty is to first of all decide whether the child is a passive actor, or whether the child can play an active role that would justify their appropriation of citizenship, political rights and of moral autonomy. 47 Liberal political thought presumes that adults are able to make rational, independent decisions, whilst children's status is one 'where adults may paternalistically choose for them'. 48 Thus,

${ }^{44}$ Emma R othschild, 'A n Infinity of G irls: The Political Rights of Children in H istorical Perspective', paper for Centre for History and Economics (M ay 2000), p. 5. Indeed, as R othschild notes: 'the failed apogee of the summer of 1794 was to have been a 'fate Heroique' for the internment of the remains of Bara and Viala ... the urn of Viala to be carried by young republicans, 'from the ages of 11 and 13 inclusively', the dancers to perform 'lugubrious and military pantomimes', the music to express 'heartrending sounds'.

45 D avid Boucher, Political Theories of International Relations (Oxford: Oxford U niversity Press, 1998), p. 380.

46 Judith Ennew, 'H ow Can We D efine Citizenship in Childhood?', working paper, Harvard Center for Population and Development Studies, vol. 10:12 (October, 2000).

47 J ohn O'N eill, 'Is the Child A Political Subject?', Childhood: A Global Journal of Child Research, 4 (1997), p. 241.

48 D avid A rchard, Children, Rights and Childhood (London: R outledge, 1993), p. 53. 
although the liberal theorist places emphasis on the individual as the significant actor in the dynamics of the market, this individual is an amorphous generalisation neither woman nor child, nor part of a familial societal, or household, grouping that itself impacts upon the individual's set of economic and political choices. ${ }^{49}$ The structuralist perspective is similarly nebulous in that, despite Marx's concerns regarding child labour as an example of a particularly exploitative labour relationship, ${ }^{50}$ the emphasis upon class in $M$ arxist analysis can be said to negate the impact of children as actors themselves. Similarly, later structural analyses that concentrate on the distinction between North and South do not provide the answers either. Children face different problems depending upon the economic conditions under which they live, ${ }^{51}$ but being classed as either rich or poor does not necessarily impact upon the way in which children are received upon the international political stage.

That these 'traditional' theories might have difficulty in incorporating 'new' actors - in this case children - is unsurprising, given that the raison d'être of critiques against them is to highlight just such inadequacies. However what is perhaps more surprising is that in none of these reactions against the dominating discourses in international relations theory is there mention of the child, despite the fact that the policy of, for example, both critical theorists and postmodernists is to expose 'historically constructed myths', 52 and childhood itself has been described as just such a construction. $R$ ather, their concerns remain with the historically constructed myth of power, as traditionally conceived. ${ }^{53} \mathrm{~F}$ ocusing upon children as a potential site of knowledge within the mainstream IR discourse thus challenges the conception of power in the international system as we know it, and how it is reflected in academic analyses. By concentrating on the dominant, rather than upon the 'muted' in the international system, ${ }^{54}$ the discourse that has evolved answers only part of the question, reflecting 'how a form of ideological scripting masks the limitations, exclusions, and silences connected with the recognised forms of the dominant public-policy discourse'. 55

49 O'N eill, 'Is the Child A Political Subject?', p. 243.

$50 \mathrm{M}$ ore recently, Smith and Wallerstein moved beyond the concept of the unitary male breadwinner to include men's, women's and children's labour pooled as part of a family's income-earning strategies. Looking at the entire household in this way - as opposed to simply the male breadwinner in the household - was crucial to their attempts to make sense of different wages paid in different parts of the world for the same kind of work. See J. Smith and I. W allerstein (eds.), Creating and Transforming Households: The Constraints of the World-Economy (Cambridge: Cambridge U niversity Press, 1992).

51 F or those countries with high levels of poverty and concomitantly high levels of child labour, the issue of securing improved legislation to protect children under such conditions may be the most immediately significant on the activists' agenda. On the other hand, where a child lives in a country which is economically much more secure, the issues that may be of more immediate significance may be ones advocating greater citizenship rights or input into the policymaking process in the country as a whole.

52 D avid Boucher, Political Theories of International Relations, p. 17.

53 F or this reason, F rost calls postmodernists 'super-R ealists'. See Boucher, Political Theories of IR, p. 376, and M ervyn F rost, Ethics in International Relations: A Constitutive Theory (Cambridge: Cambridge U niversity Press, 1996), p. 68.

54 E. A rdener, 'The problem revisited', in S. A rdener (ed.), Perceiving Women (L ondon: D ent, 1975).

$55 \mathrm{M}$ ichael J. Shapiro, The Politics of Representation, p. 5. H e goes on to note: 'W ithin a linguistically self-reflective posture, the analysis of public policy deploys itself on a broader terrain to include not only what a society tends to regard explicitly as its problems but also the policy immanent in the ideas of the self and the order within which what is commonly thought of as public policy is executed'. 


\section{An inclusive discourse?}

If then children, and their place in IR, could be taken into account, the question remains what the usefulness of such a move would be and how overcoming their neglect in the mainstream IR discourse might change the landscape of the discipline if, indeed, at all. In answer to this there are probably numerous ways that their inclusion might change the landscape, though some are more obvious than others. This section focuses upon three in particular: agency, citizenship, and community.

The question of children's agency holds a central position within the existing childhood studies literature, and particularly in debates over how the notion of childhood itself is constructed. Childhood, and determining the end of that childhood, can be perceived as a social construct with age the determining factor in recognising a person's supposed social, political, legal and economic competence. ${ }^{56}$ Interestingly, for example, Smith notes that as far back as 1872:57

the child is clearly set up as possessing agency when in fact he has been constructed by the adult as agential specifically so as to be found wanting; the artifice identified as covering a lack has of course been projected onto the child by the adult.' 58

M oreover, the construction of childhood is fluid - it has altered throughout history and across cultures and this, in turn, has an impact upon how the child is viewed at any point in time, and upon how their childhoods are reflected within society. A this particular point in time, there seems to be a basic agreement, particularly where the international system is concerned, that children either lack, or have limited, agency. Therefore, despite the fact that during the past half century the study of childhood has become routine for the psychologist, the sociologist, the philosopher and the anthropologist, confusion remains about the efficacy of the concept of childhood itself, and of its historical, cultural, legal, and indeed ethical, implications. 'Childhood' is a contested construct, and one that may, ultimately, be flawed. Tamar Schapiro, for example, in an analysis aimed at demonstrating the usefulness of $\mathrm{K}$ antian ethics in considering the question of ' what is a child?' asserts that 'childhood ... is essentially a predicament' in that 'the condition of childhood is one in which

56 There is also, of course, debate regarding the beginning of childhood, which the U N CR C left unresolved. Thus the Preamble to the 1989 CR C contains a provision citing the 1959 D eclaration of the R ights of the Child ... to the effect that children need special safeguards 'before as well as after birth'. However, the legal effect of this provision is mitigated by a statement that was included in the travaux preparatoires as a compromise between those states who oppose abortion and those who do not. By making it clear that the Preamble does not grant the foetus an absolute right to life, this statement essentially retains the status quo, leaving the question of when childhood begins to individual state discretion. See J enny K uper, International Law Concerning Children in Armed Conflict (Oxford: Oxford U niversity Press, 1997).

57 Lindsay Smith, The Politics of Focus: Women, Children and Nineteenth-Century Photography (M anchester: M anchester U niversity Press, 1998), p. 114.

58 Such notions are reflected too in nineteenth century literature. F or example in many of the works of Charles Dickens, agency translates to wilfulness, albeit with the possibility of redemption. As W ilt notes: 'all D icken's children [are] cruelly tried and "bent" before the dawn of consciousness, but along that bias [choose] a full and flexible shape - which promotes alike the doing and the winning, the loving and being loved, the seeing and the being recognised.' See J udith W ilt, 'Confusion and Consciousness in Dickens's Esther', Nineteenth-Century Fiction, 32:3 (D ecember 1977), p. 288. 
the agent is not yet in a position to speak in her own voice because there is no voice which counts as hers'. 59

In terms of IR discourse, considering that children might have agency challenges the rather narrow way in which the agent-structure debate is currently viewed by bringing out the distribution of power that may exist between sections of a given society and the differences that result from it. Of immediate significance here is the whole framing of the agent-structure debate. Blieker, for example, argues that the 'notion of structure .... is intrinsically linked to neo-realist, statist and spatial perceptions of world politics'. ${ }^{60}$ This also brings out the issue of the types of agency that are attached to different actors. Acknowledging the significance of children within this discourse may thus allow for a fuller understanding of what agency means, and may result in the inclusion of children as 'knowledge agents' whose presence may contribute to the demarcation of the discourse itself. F or example, in some senses states are more accepting of the notion that children can acquire 'negative agency' as opposed to 'positive agency'. Thus, children may be held responsible for the crimes that they have committed (negative agency) at an age when it is generally assumed that they are too young to make any particular positive societal contribution (positive agency). This is partly a concern with what Sharon Stephens has termed 'risky children' - those such as child labourers or child soldiers, or even child refugees who need to be controlled in ways that will not threaten the existing societal order, or indeed will not cause too much upheaval in the rapidly changing global one. ${ }^{61}$ Such conceptions also have a historical precedent, however, in that they reflect the historical perception of the child as either Dionysian - whereby the assumption is that the child is inherently evil or corrupt - or Apollonian whereby the assumption is that children enter the world in a state of innocence, untainted by the world around them. ${ }^{62}$

Of course this notion of children's agency also raises the issue of rights, in that the claims made regarding child agency are often couched in the language of rights. We can see this in the UNCRC which is very much couched in terms of the acknowledgement of children's rights as a fundamental part of the process of securing children's future. ${ }^{63}$ Some authors have even argued that the adoption of the U N CR C signals an 'explicit recognition that children have civil and political rights, in addition to the more generally accepted rights to protection and provision'.64 $M$ oreover, the idea that children possess rights that adults should not only respect but also help to promote now informs aspects of governmental policy and legislation, as well as the policies of voluntary sector and charitable organisations and welfare

59 Tamar Schapiro, 'W hat is a Child?', Ethics, 109:4 (1999), pp. 716, 729. Interestingly, Schapiro also takes time to mention the difficulty in classing everyone under the age of 18 as a child in that 'children at different stages of development differ from one another in the extent of their hegemony over themselves' (p. 734).

60 Blieker, Popular Dissent, Human Agency and Global Politics, p. 11.

61 Sharon Stephens (ed.), Children and the Politics of Culture (Princeton, N J : Princeton U niversity Press, 1995).

62 See Chris J enks, Childhood (L ondon: R outledge, 1996), pp. 70-8, for a fuller discussion.

63 The UNCRC also, however, is a mix of rights and obligations. The language may mention rights, but there is a sense too of the obligation upon states of ensuring that children actually achieve these.

${ }^{64}$ Children's R ights D evelopment M ovement (1994), p. 3 taken from R uth Lister, Citizenship: Feminist Perspectives (Basingstoke: Palgrave M acmillan, 1997), p. 77. 
professionals. ${ }^{65} \mathrm{H}$ owever, in certain senses the jury is still out regarding the actual nature of rights as they relate to the child. Indeed, as H ughes has acknowledged, an interest in enhancing the rights of the child may actually have very little to do with children per se and much more to do with critiquing those liberal democracies whose foundations are perceived to be fatally flawed because they allow the exclusion of any group in society from full political status and involvement. 66 Onora 0 ' $\mathrm{N}$ eill has even questioned the use of the language of rights itself when approaching ethical issues as they relate to the child, arguing that a focus on obligations may be more relevant when trying to safeguard children's well-being. ${ }^{67} \mathrm{~F}$ or $\mathrm{O}^{\prime} \mathrm{N}$ eill this goes back to the question of the dependence and vulnerability of children. Because children actually are dependent (unlike other 'oppressed social groups' who may find themselves in a plea for rights), she argues that the focus should change from the rights of children to the obligations of adults to them. Interestingly, however, O'N eill too is concerned with the issue of the definition of childhood, recognising concerns with the variety of experiences under the age of 18 and characterising 'mature minors' as a group who can find themselves in a position partly analogous to that of oppressed social groups. In this case, the rhetoric of rights may indeed be of use to those who find themselves with mature capacities but still with the burden of minority. ${ }^{68}$

Significantly, debates of this nature open up more general questions regarding how the landscape of the discipline might change by including children in it, such as the role of the child in both domestic and international politics, for example whether children should be allowed to vote, ${ }^{69}$ the degree to which the state should be involved, if indeed it should at all, in a child's social and cultural development, and the dynamics of the relationship between childhood and political socialisation. This question of children and voting is particularly pertinent here, given that one of the ways in which it is argued that the problem of voter apathy in W estern societies may be addressed is through giving the vote at a younger age, a debate that surfaces every so often in academic debate, and as a matter of public concern. ${ }^{70} \mathrm{~F}$ or example, in M ay 2004 in the U nited States, a bill designed to get more youth involved in the elections process passed the California state Senate Committee on Elections and R eappointment. The bill, which was proposed by Senator J ohn V asconcellos, would lower the state's legal voting age to 14. Although the proposed constitutional amendment would give 14- and 15-year olds only one-quarter of a full vote, while 16 and 17-year olds would get half a full vote, Vasconcellos argued that such a move would be designed to encourage early and regular voter participation among young

65 Bob F ranklin, 'Children's R ights: An Introduction', The New Handbook of Children's Rights, Comparative Policy and Practice (London: Taylor and Francis, 2002), p. 3.

${ }^{66} \mathrm{~J}$. Hughes, 'Thinking about Children', in G. Scarre (ed.), Children, Parents and Politics (Cambridge: Cambridge (Cambridge U niversity Press, 1989).

67 Onora O'N eill, 'Children's R ights and Children's Lives', Ethics, 98:3 (1988), p. 459.

${ }^{68}$ Guido M aggioni and Claudio Baraldi, Children's rights and contemporary sociological perspectives on childhood', 〈www.cirfid.unibo.it $\rangle$.

69 In N orway, for example, there have at times, though admittedly without much support, been proposals put forward to give children the right to vote. See A nne Trine K jorholt, 'Small is Powerful, D iscourses on "Children and Participation" in N orway', Childhood: A Global Journal of Child Research, 9:1 (2002), pp. 63-82.

$70 \mathrm{H}$ owever, $\mathrm{M}$ artha $\mathrm{M}$ inow has bemoaned the failure of the children's rights movement, and lists as the first cause of failure the fact that children do not vote and that their voice is not adequately represented. See, for example, M artha M inow, Not Only for Myself: Identity, Politics and the Law (L ondon: The N ew Press, 1997). 
Californians by affording them a real live stake in the political process. Vasconcellos dubbed his bill: 'Training Wheels for Citizenship'.71

The frequent absence of children from discussions of citizenship can be seen as indicative of the position of the rights of children in any given society. Indeed, it harps back to questions raised regarding the division of society into the assumed public and private space. $\mathrm{H}$ owever, it can be argued that the consideration of who are or aren't citizens is also a construction as opposed to any 'perennial' notion of who citizens are when placed in historical perspective, or indeed of what they do in order to attain the title 'citizen'.72 Lister, for example, argued that participation in community projects at a neighbourhood level should be recognised as citizenship (provided it is not at the expense of other people's rights as citizens). ${ }^{73} \mathrm{U}$ nder such circumstances, the work of children in N orway's Children's M unicipal Committees (and in the participatory budget councils of Barra $\mathrm{M}$ ansa) should confer such recognition and also contribute to their identification as political beings. ${ }^{74} \mathrm{This}$, in turn, contributes to the building of a sense of political competence which, as Patemen argues, is a necessary condition of active citizenship. 75 They have assumed responsibilities, which in turn results in a conferral of rights. ${ }^{76} \mathrm{~A}$ gain, then, the question of the rights of children, and our obligations to them, becomes significant.

M oreover, the recognition of children as 'active' citizens may have a more wide-ranging impact in that extending the notion of citizenship creates possibilities for extending the moral and political boundaries of the community - there is no longer the assumption that political community requires a collective identity that all members are obliged to share. Examining children and their place in the system may then give us some insight into the nature of political community in international relations in general. ${ }^{77}$ Indeed, the role of children may be one of the most obvious places for the 'open dialogue' regarding the appropriateness of exclusion from a given community to be examined. ${ }^{78}$

71 Bay City N ews Service, 'Bill to L ower Voting A ge to 14 Passes Senate Committee', M ay 7, 2004.

72 M ichael J. Shapiro, The Politics of Representation.

73 Lister, Citizenship, p. 40. Lister was talking about the case of women, but similar arguments can be made with regard to children.

74 While recognising the dangers of romanticisation of what can be frustrating and exhausting work, political participation, in whatever sphere, contributes to the identification of 'women as political beings' See bell hooks, Feminist Theory: from Margin to Center (South End Press, 1984), p. 127.

75 Carole Pateman and M. Shanley (eds.), Feminist Interpretations and Political Theory (Cambridge: Polity Press, 1989).

76 Lister, Citizenship, p. 77: 'One group of children who could be said to have demonstrated at least some of the capacities for citizenship through their exercise of some of its responsibilities, often to the detriment of the rights enshrined in the UN Convention, are those providing community care for a parent or relative. Their existence in a number of W estern European countries has only recently been partially recognised.'

77 If we examine the question of children's identification with political community we are, of course, back into the realms of political socialisation, which may take place at an age much younger than we may assume. Indeed more than forty years ago Easton and $\mathrm{H}$ ess were arguing that by the time children have reached the age of seven, the majority have formed a strong attachment to their own political community. D avid Easton and Robert D. Hess, 'The Child's Political World', Midwest Journal of Political Science, 6:3 (A ugust 1962), p. 236.

78 A ndrew Linklater, The Transformation of Political Community: Ethical Foundations of the Post-Westphalian Era (Cambridge: Polity Press, 1998), p. 220. 


\section{Conclusion}

This article has demonstrated that the exclusion of children, and the examination of their role, from mainstream IR discourse is an oversight that is long overdue for correction. Other areas of social science have acknowledged the fundamental role played by children within them and there is no reason, other than those boundaries of our own making, that our discipline cannot do the same. At the very least, acknowledging their presence adds to the panoply of actors who both affect and are affected by, the dynamics of contemporary international policymaking. At the very most, acknowledging children may change the focus of the discipline and, indeed, may cause us to look at some of the age-old dilemmas of IR - such as the nature of war, and the solutions for peace-in an entirely different, and more inclusive, manner. 